\title{
Skills Requirements for Engineering Graduates: Industry Perspective
}

\author{
O. P. Shukla ${ }^{1}$, Suresh Garg ${ }^{2}$ \\ ${ }^{1}$ Joint Director, Department of Training and Technical Education, Govt of NCT of Delhi and Research Scholar \\ at Delhi Technological University, Delhi, \\ ${ }^{2}$ Professor, Delhi Technological University, Delhi,India,
}

\begin{abstract}
In the last few years, it has been observed through various surveys and seminars that the large number of engineering graduates is not employable. One of the important reasons for that is the lack of necessary skills in them. Though the purposes of education is the holistic development of the graduates and make them strong in fundamentals, but it cannot be denied that in the present economic environment, developing necessary skills is also important. In this context, this paper presents the results of the survey of industry executives visiting campuses for placement to find out the skills required by the industry so that the curriculum can be revised and delivery mechanism augmented to prepare students with desired skills.
\end{abstract}

Keywords: Skill Development, Engineering Education, Employability, Industry

\section{Introduction}

The Knowledge Commission of India had indicated that the country will need more than 1,500 universities by 2015 to provide opportunities of higher education to eligible Indian youths. Today the country has more than 700 universities and more than 33,000 colleges which offer a large number of programmes in Arts, Science, Commerce, Finance, Engineering, Technology, Law and Medicine. The country has grown in terms of number of colleges, universities and programmes, but it seems that there is a huge gap between the quantity and quality of higher education offered in this country. It seems there is lack of proper planning, appropriate guidelines, and corrective measures while sanctioning new institutions and disciplines Most of the technical education institutions including the better known ones are understaffed and lack in qualified, competent and suitable faculty members.

In most of the engineering institutions the course curriculum is, by and large, theoretical in nature and students are not made aware of the applications of the theories in industry. The programmes and their course content reflect lack of interaction among academic institutions and industries. In the process the curriculum quite often fails to meet the needs of the industries. Not many structural changes have taken place in the curriculum even though rapid developments have been taking place continuously in the fields of science and technology. New branches of engineering have been introduced with the structure remaining in the traditional mode.

Moreover, the institutions mostly follow the traditional method of teaching giving little thought to the fact that information nowadays is readily available on the net and thus students would not get interested unless they get something extra by attending classes. It is more of content delivery than knowledge delivery. The assignments given quite often are routine and do not involve any research or innovation. It is a great challenge to motivate and attract students to serious learning. Moreover, the evaluation system has not been made robust enough to find out the knowledge level of the students. The philosophy of the semester system and the continuous evaluation process are not being understood by the students and also by the faculty members. Thus they are applied in a routine manner and the students concentrate only on grades and not on learning.

The emergence of the IT sector has also affected the quality of graduates in other traditional engineering disciplines. Knowing that it is easy to get a job with a high salary in the IT sector, students from other disciplines also take as many IT related courses as possible as electives and do not give much importance on their discipline subjects. Moreover, the emphasis on soft skills during campus interviews has created a wrong notion among students. They give too much importance on the development of soft skills and ignore the subjects of their disciplines. It seems employers have also accepted the fact that students with soft skills can be trained in the industry and thus do not expect a high level of knowledge in discipline subjects.

Thus effort is needed to produce readily- employable technical man power in the country. The improvement of infrastructure, redesign of curricula, improvement of teaching-learning methods and attracting well qualified teachers are only a few steps that could be initiated by individual institutions. The main challenge is to create an academic environment and education system that promote and ensure learning. However, there are many external and societal factors that need to be addressed. As per report, Nasscom is aimed at incubating, funding and supporting 10,000 technology startups in India over the next ten years to overcome with 
unemployment problem. Its vision is to foster entrepreneurship, build entrepreneurial capabilities at scale and strengthen early stage support for tech start-ups by bringing together key stakeholders of the eco-system including startup incubators/accelerators, angel investors, venture capitalists, startup support groups, mentors and technology corporations. Workforce Development Enhancing employability and access to a skilled talent pool is a critical enabler for India's competitiveness. NASSCOM is engaging with a broad spectrum of academia, industry and governments to devise policies, curriculum and assessments that achieve this objective. In order to enhance the employability of the talent pool in the country the NASSCOM IT-ITeS Sector Skills Council has launched the many programmes to suggest measure enhancement in employability skill to produce industry ready graduates and creating employment to some extent by entrepreneurship The steps taken by NASSCOM are summarised as under.

- $\quad$ NASSCOM Assessment of Competence (NAC): An assessment and certification framework that ensures a steady supply of quality professionals to meet the present and future requirements of the IT-BPM industry

- Global Business Foundation Skills (GBFS): Programme to help increase the industry readiness of students who intend to have a career with the BPM industry

- Foundation Skills in Information Technology (FSIT): Programme to help increase the industry readiness of students who intend to have a career with the IT industry

- NOS (National Occupational Standards) across verticals in the IT-BPM industry: Performance standards that individuals must achieve when carrying out functions in the workplace, together with specifications of the underpinning knowledge and understanding Enabling Environment. The National Skills Registry (NSR) NASSCOM in partnership with the industry has developed the National Skills Registry (NSR), a unique national database of registered and verified knowledge workers in the sector. Launched in 2007, this database is managed and run by NSDL Database Management Ltd. (NDML), a fully-owned subsidiary of National Securities Depository Ltd. (NSDL). NSR aims to build a robust and credible information repository on the knowledge professionals in the IT-BPM sector. The benefits of NSR flow across to clients, service providers and employees. NSR has enhanced the value proposition of the Indian IT-BPM industry and raised the bar on security standards in pursuit of excellence and client satisfaction.

- The Data Security Council of India (DSCI) - A not-for-profit organisation established in 2008 with the key objective of building a credible and committed body to uphold data privacy and security standards. The mission of DSCI is to build the trustworthiness of Indian organisations as global sourcing service providers and to send out a message to clients worldwide that India is a secure destination for outsourcing. Its aim is also to reiterate that in India, privacy and protection of customer data is enshrined in the global best practices followed by the industry.

- NASSCOM Foundation (NF) - Was set up as a trust in 2001. It was instituted with the aim of using information and communication technologies for development (ICT for D), and to catalyse Corporate Social Responsibility (CSR) initiatives within the Indian IT-BPM industry. By implementing a diverse range of programmes, NF is taking information and communication tools to underserved communities across the country. It is also channelising the immense potential of the IT-BPM industry towards socioeconomic development of the nation.

- The National Institute for Smart Governance (NISG) - Incorporated in 2002, the National Institute for Smart Governance (NISG) is a Section 25 organisation set up in public-private partnership with NASSCOM, the Government of India and the Government of Andhra Pradesh. The key objective of the organisation is to catalyse the roll out of e-Governance projects

\section{Literature Review}

Bektaş and Tayauova (2014), mentioned Higher education institutes (universities) make important contribution to the economy and social life. So universities effectiveness is important for industry. Cooperation between university and industry can facilitate the transfer of knowledge and stimulate the production of new knowledge and technology. University knowledge is applied in industry to support innovation and creation for new technology. University-industry cooperation both fosters new university capabilities and effectiveness of higher education.

Johan (2015) studied about preparing the undergraduates especially the graduating students with employability skills. In the context of Malaysia Technical University Network (MTUN), the graduating engineering students were expected to be good both in academics and the soft skills in particular of being ready to work as engineers. In line with the National Graduate Employability Blueprint 2012-2017 published by the Ministry of Higher Education Malaysia, one of the approach opted that getting the knowledge of being an engineer is to learn and experience it from the engineers themselves and so suggested the lecturer to be an engineer himself preferably with a long attachment in the industry. Such experiential learning is feasible if the university lecturers have exposure to industrial experience as engineers and the students have certain level of 
fundamental knowledge to maximize the learning process. The study indicated the perception of the students to the lecturers with such engineering experience towards their learning experience

The findings supported the strategy of technical universities which are highly required to hire lecturers with industrial experience. The study mentioned about good benefits in the context of bringing them the experience of working in the industry into the classroom.. In the context of employability skills, teaching engineering courses with industrial experience is an advantage to the institution as not only the learning content is delivered in the class but also skills which are indirectly taught in the learning process. This high perception of the students which is demonstrated as more than $80 \%$ in cumulative percentage suggests that the students perceive the lecturers as someone who can add value to them i.e. promote high self-esteem, open minded to creative problem solving ideas and demonstrate high professionalism. These are all essentials traits of a role model for them to refer to in preparing them to be good engineers.

McMurray et al. (2016) studied about important factors considered while recruiting Graduates by Industries. The result indicate that "Personal Attitude" was most important followed by Employability skill and Relevant work experience .The research also found the important transferrable skills and Trustworthiness was found most important followed by reliability, motivation and communication. Wickramasinghe and Perera (2010) studied about Employers perception towards Employability skill. The author observed higher employability skill in female graduates with highest mean of 4.33 in Basic Arithmetic where 4.18 for male graduates. The Punctuality also found higher in female graduates with mean of 4.33 against mean of 3.93 in male graduates. However the other skill like Problem solving skill was found higher in male graduates with mean of 3.89 against 3.56 in female graduates.

Murali and Rajaram (2015) studied the corporate expectations from engineering graduates and observed that earlier corporate industries used to hire fresh graduate engineers based on their academic qualification shown through their marks and technical skills, but now there is need for the graduate engineer to have other skills like soft-skills. This may be due to the rapid growth in technology, the dynamic world economy, the increased influence of information technology, the ever rising competition and globalization. It was also identified communication skills as the critical requirement for them under the category of soft skills followed by positive attitude. It was also evident that the engineering institutes have now started focusing on the soft skills, with interviews leading followed by Personality Development. Approximately $98 \%$ of the graduates are aware that positive attitude plays a major role in acquiring and maintaining a job placement. Zaharim et al. (2010) did study to identify the perception and the expectation of employers on skills owned by engineering graduates in their work place. The finding indicated that the majority of those companies employing graduates have been satisfy with the knowledge and skills of the graduates they recruit. The expected skills from graduates were:

a. Ability to function effectively as an individual and in a group with the capacity to be a leader or manager as well as an effective team member.

b. Ability to communicate effectively, not only with engineers but also with the community at large.

c. Ability to undertake problem identification, formulation and solution.

d. Ability to acquire and apply knowledge of engineering fundamentals.

e. Having competency in engineering application and orientation.

f. Ability to utilize a systems approach to design and evaluate operational performance.

g. Recognizing the need to undertake lifelong learning, and possessing/acquiring the capacity to do so.

h. Ability to design and conduct experiments, as well as to analyze and interpret data.

i. Having the competency in theoretical and research engineering.

j. Having in-depth technical competence in a specific engineering discipline.

k. Having social awareness, cultural, global and environmental responsibilities and ethics of a professional engineer and the need for sustainable development.

1. Having the knowledge of contemporary issues.

m. Having basic entrepreneurial skills.

With mean value above 3.5 all categorically of skills as listed were found important except basic entrepreneurship skill Shamshina (2014) investigated the requirements of technical university graduates (communicative readiness, creativity, positive relation to the profession, methods of the technical and economic analysis, etc.), the notion of professional competence, based on the federal educational standards and data from the interviewing industrial employees, is highlighted as one of the professional skills required of a bachelordegree-holding engineer working in the engineering industries Baharom et al (2014) observed that in addition to technical competence and soft skills, graduates' business acumen has also been identified as crucial to their well roundedness to suit the Industries. In realizing this initiative, Malaysian institutions of higher learning are now working towards incorporating elements of business acumen in their curriculums. Universiti Teknologi PETRONAS, the higher learning institution in which this research had been undertaken, is one such educational establishment that inculcates business acumen skills in its graduates. The study aimed to gauge the level of 
business acumen skills the students demonstrated during their seven month internship period. Descriptive statistics were computed to find out the interns' level of business acumen (behaviour, attributes, skills and ethics) as rated by their supervisors. The results indicate means scores ranging from 3.24 to 3.71 , the interns were rated as possessing considerably high business acumen levels by their internship supervisors. Notably, the interns were rated very highly on entrepreneurial ethics (mean 3.71), signifying the possession of good ethical values among the interns. The interns were however, rated the least (mean 3.24) on entrepreneurial skills Azevedo et al (2012) proposed a conceptual framework and industry-driven approach to measure required competencies of business graduates. The suggested approach was designed and tested within a project implemented in Austria, the UK, Slovenia and Romania. Evidence from this multi-country study of employers and business graduates suggests that it is possible to investigate industry requirements with a cluster of eight key generic competencies. Competencies were selected following a detailed analysis of academic literature and 39 semi-structured qualitative interviews. A survey was conducted with 900 business graduates and employers in four European countries. The survey confirmed that the eight key competencies selected were both valuable for business graduates' current job performance as well as relevant for future career development. Survey results showed that employers were not very confident in the level of capability of business graduates in the eight competencies investigated in this study. Results are consistent with other empirical evidence concerned with graduates' level of key generic skills and highlight the need to strengthen competency development within undergraduate business education. The competency critical and analytical was found most important followed by team work and relationship building among Influencing and persuading, Teamwork and relationship building, Critical/Analytical, Self and time management, Leadership, Ability to see the bigger picture, Presentation, Communication.

Moreno et al. (2012) studied to help both academia and the software industry form a picture of the relationship between the competences of recent graduates of undergraduate and graduate software engineering programmes and the tasks that these professionals are to perform as part of their jobs in industry. It was studied that the core knowledge suggested by graduate and undergraduate SE educational recommendations and its relationship to representative tasks to be performed by a software practitioner according to industry. The biggest gap found concerns tasks associated with the IT Business Consultancy profile. Knowledge required by such tasks is beyond the classical technical knowledge that we are accustomed to in most undergraduate and graduate SE programmes. In this respect, the results were consistent with other studies that claim there is a need to move from technical to the business issues (Gartner, 2005; Davey and Tatnall, 2008) Kazilan et al. (2009) investigated the level of employability skills among the students of technical and vocational training institutions. The finding showed that the majority of the respondents were male. Most of them pursuing education in Certificate of Skills in one of these five areas of specializations: art and building, electric, electronics, automotive and mechanical. The finding indicated that the employability skills among students were average. The findings also show that there was a significant difference between employability skills and area of specializations. There were significant difference between employability skills for basic skills and informational skills and gender. The study suggested that Technical and Vocational Educational Department should provide a curriculum which includes employment element skills which are needed by the employers.

The employability skill found most important are Personal Quality Skills- 4.13 followed by Interpersonal Skills -3.95, Basic Skills- 3.84, Thinking Skills- 3.81, Resource/ Capability Skills- 3.79, System and Technology Skills- 3.78, Information Skills- 3.74. The Personal Quality skill includes Responsibility, Self Confidence, Sociability, Self Management, Honesty, punctual and efficient, Adaptable and flexible, self control/ self directed, Good work attitude.

Adeyemo et al (2010) studied about high levels of unemployment and prospects for employment in Nigeria. It was studied whether the education they receive not in consonance with today's skill requirements in the labour market or is the curriculum used in the higher institutions too outdated? Many employers of labour usually complained that graduates are poorly prepared for work. They believe that academic standards have fallen considerably over the past decade and that a university degree is no longer a guarantee of communication skills or technical competence. It seeks to answer these and other questions regarding the levels of graduate preparedness for productive employment. The findings showed that many science graduates were not good enough in technical and practical skills, poor in entrepreneurship skills and are deficient in information technology skills. It was suggested that university departments will need to change their curricula every two or three years in order to ensure that the content of their teaching reflects the rapidly advancing frontiers of scientific knowledge and the global market. Furthermore, employers are increasingly demanding new curricula that include skill standards and perhaps even vendor-specific certifications that are not typically included in traditional university curricula. These employers simply do not trust that the traditional, faculty developed curriculum will meet their needs especially in the area of information technology as different companies now adopt new vendor products and then search for individuals who have mastered the technology Remaud et al. (2010) studied about Internships as a widely established practice in French engineering schools, encouraged for 
improving employability but also supervised by CTI(an accreditation agency in France. The findings were are drawn regarding the main challenges affecting industry internships and the impact of this practice into engineering education quality

The French engineering accreditation body (CTI -Commission des Titres d'Ingénieur-) establishes, for all French five-year engineering master programs, a minimum internship period of 28 weeks (14 of them must be compulsory done in industry, whereas the rest could be done in a research laboratory). It is recognized to have a number of positive effects, such as increasing the short-term employability and the international mobility of engineering graduates. Integrated internships within the French engineering curriculum have a long history and currently constitute an important component of the French engineering curriculum. The different international accreditation experiences indicated that the French internship model could be successfully, if not exported, at least adapted to institutions in other countries.

Collet et al. (2015) investigated about graduate skills and employability, the absence of a shared language between student, academic and industry stakeholder groups means that defining industry skills requirements is both essential and difficult. The research is to assess graduate skills requirements in a knowledge-intensive industry from a demand perspective as distinct from a curriculum (supply) viewpoint.

Skill items were derived from a breadth of disciplines across academic, policy and industry literature. CEOs and senior managers in the innovation and commercialisation industry were surveyed regarding perceptions of skills in graduates and skills in demand by the firm. Two rounds of exploratory factor analyses were undertaken to examine employers' perceptions of the skills gap. The findings indicated the ten broad constructs of skills and found. Knowledge, leadership and inter professional collaboration feature as prominent skills. The second-order analysis revealed employers' perceptions of graduate skills specifically centre on organisational fit and organizational success.

\section{Industry Needs And Expectations}

The following attributes are considered in this study to assess the industry needs:

\section{A Engineering Knowledge}

Advancement of engineering knowledge is urgently needed in order to guide engineering educators in meeting the requirements of engineering industry in the 21st Century. Labour market becoming more competitive and depends on quality of knowledge and skills as the globalization come across in all industry. The Rapid and drastic changes in economic growth are creating higher demands for these competencies in the workforce. There exists strong evidence for improvement of basic competences: underlying science knowledge, knowledge of fundamental and advanced engineering, engineering reasoning and problem solving, systemic thinking, as well as conceiving, designing, implementing and operating systems in companies and in social context.

The rapid growth of engineering knowledge has resulted in continuous expansion of novel technologies and materials that can be used in designing new products and processed. Computer- and web-based technologies allowed engineers to significantly shorten the development of novel artefacts. These advances intensified the competition between engineering companies and shortened the lifespans of the majority of engineering products. As a result, practicing engineers are now expected to deliver creative designs to markets much more swiftly than ever before (Belski et al, 2016).

\section{B Problem analysis}

Engineering profession is often associated with extensive problem solving. Therefore the ability to solve problems creatively has been identified as one of the imperative competencies for graduating students by engineering associations worldwide (Engineering Council, UK, 2013). Problem solving or critical thinking abilities are the skills that promote technological innovations.

It has been reported that the traditional methods of teaching engineering students do not necessarily succeed in enhancing their problem solving and creativity skills (Belski et al., 2013; Douglas et al., 2012). (Belski, 2015) have suggested the methods ie. Smart Little People, the Size-Time-Cost operator and the notion of the Ideal Ultimate Result (IUR) which are likely to help students in acquisition of effective problem reframing and problem definition routines. Availability of positive attitude among graduates also helps in fostering skills such as problem solving, decision making, broad mind, trustable, able to cooperate and be effective (Buck and Barrick, 1987). Employers value such skills in every individual at the time of interview. Positive attitude towards work has been identified as important employability skill by graduates, employers and university lecturers (Wickramasinghe and Perera, 2010).

\section{Design/Development of solutions}

Engineering institutions in India have to look for solutions to overcome the challenges of skill development among graduates. This requires curricula that are designed to incorporate a balance between 
theoretical and practical perspectives with an applied emphasis on industrial relevance. Students' learning experience can be greatly enhanced by acquiring knowledge and skills that have lifelong impact. Competency in both theory and practice of instructors is a key asset to the transformation of learning experience within and outside the classroom for learners. The success of knowledge facilitation within learning communities begins with the fundamental utilization of instructors' core skills in simplifying complex concepts for the relevance of the current environment (Yeo, 2009). Effective Course or curriculum design emphasizes knowledge construction by providing students with learning opportunities to participate in a broad range of research activities (Webster and Kenney, 2011).

Glomann (2015) have implemented the Human-centered design (HCD) approach in order to promote experiential learning. It starts with the activity of understanding and specifying the context of use, followed by the specification of the user requirements with reference to design thinking activities. At a later stage, students are required to put their acquired knowledge into practice by producing their own design solutions; these are then evaluated and improved accordingly. In the end, the students will have learned about the foundations of $\mathrm{HCD}$ in both a theoretical and a practical way.

\section{$D$ Ability to conduct investigation of complex problems}

Theoretical knowledge itself is not useful until it is applied for solving complex problems. In today's rapidly changing competitive world, young graduates need to develop these competencies. They should possess the ability to identify problems faced by society and find out the appropriate solutions. Industry also demands such employees, who respond to the problem quickly, and take right decisions.

\section{E Modern tool usage}

The rapid development of the current working world needs proficient workers mainly in fields which involved latest technologies. Therefore, the engineering graduates must be prepared to upgrade their skills to match the latest technology, particularly applicable for IT engineers. An engineer is expected to be smart enough to widen his horizon of knowledge as per the latest trends.

The objectives and mission of corporate social responsibility in terms of human resource development and qualifications are not limited to the commitment to answer questions about corporate needs for relevant competences (what are priority areas and what is the content of competences), but also extend to creating possibilities to acquire experiences during practical training in real working environment through performance of various tasks related to actual production/manufacturing processes for which specific technologies are used. This can be made possible only through the application of modern technological tools (Andriušaitienė, 2014).

Rapid technological development necessitates national business to buy and implement state-of-the-art technologies in order to maintain competitiveness in global markets. In this marathon of growing competition, information and knowledge are changing at an analogue pace. Therefore, teachers educating and training students who represent tomorrow's labor force should teach them skills and competences to be needed by businesses several years later (Andriušaitienè, 2014).

Bhuasiri et al. (2012) identified the critical success factors that influence the acceptance of e-learning systems in developing countries. E-learning is a popular mode of delivering educational materials in higher education by universities throughout the world. This study identifies multiple factors that influence the success of e-learning systems from the literature and compares the relative importance among two stakeholder groups in developing countries, ICT experts and faculty. This study collected 76 usable responses using the Delphi method and Analytic Hierarchy Process (AHP) approach. The results reveal 6 dimensions and 20 critical success factors for e-learning systems in developing countries. Findings illustrate the importance of curriculum design for learning performance. Technology awareness, motivation, and changing learners' behavior are prerequisites for successful e-learning implementations. Several recommendations are provided to aid the implementation of e-learning systems for developing countries which have relevance for researchers and practitioners.

Gan et al. (2015) described and reviewed several examples of web technology-enabled teaching and learning approaches at undergraduate level in an Asian institution of higher learning. The research reported on experiences made in the context of an iPad-enabled mobile learning project conducted during a Knowledge Management course (excursion) in support of the university's technology-enabled learning vision. It was followed by reflections on the deployment of a collaborative social learning platform website (Edmodo), wikiand web page-creation tools (Google Site), animated videos, etc. in elective courses on leadership and human capital management. The research also described a proven project-based learning approach adopted annually by numerous undergraduate teams of four to six students as part of their compulsory capstone course in the field of information systems. Besides documenting the multiple opportunities which interactive digital technologies offer for both instructors and students in order to learn collaboratively, it was recommended to implement and institutionalize technology-enabled teaching and learning in higher education, besides some challenges. 


\section{F Synergy between engineering and society}

Seeing the effect of globalization on the society, there seems to be an increased role of engineering education in enhancing country's technological capability and the focus should be on transforming Indian economy to knowledge economy. The educational strategy and system should strive for furtherance of knowledge. A major responsibility lies on the universities, institutions and academicians to analyze the existing knowledge and its future perspective, creating new knowledge and assimilating the new knowledge that is being generated world over (Sharma, 2012).

Institutions need to emphasize towards doing research which is relevant to business and contributing to improvements in business practices and wider society. They also need to retain a strong recognition of the need for academic independence and to produce teaching and research relevant to the needs of society and graduates who are confident, multi-skilled and critical thinkers throughout their lives, as well as to the needs of good employers (McMurray et al., 2016).

\section{G Environment and sustainability}

Education for sustainable development creates new challenges for universities where faculty and staff are expected to prepare students to meet complexities in society and take responsibility for sustainability. The need for sustainable development (SD) has become increasingly evident during the last decades, implying that universities are expected to prepare students to develop the ability to integrate social, environmental and economic considerations in future decision making (Lozano et al., 2013; Sibbel, 2009). Among the most relevant competencies for future decision makers are to understand the complexities of sustainability and to convert the knowledge of education for sustainable development (ESD) into systemic, anticipatory and critical thinking and actions (Rieckmann, 2012). This development is essential, as future professionals will be working globally with companies that increasingly have sustainability on their agenda (Kiron et al., 2012). This development puts high demands on universities to integrate SD into the functions of faculty and staff so that this intelligence permeates all activities as a university identity (Steiner et al., 2013) and is not only offered piecemeal in single course activities. The transformation towards university ESD requires three elements to function: SD orientation integrated in university activities, education about sustainable development and education for sustainable development in society (McKeown et al., 2002).

\section{H Ethics}

Besides acquiring Core business skills, Problem solving skills, communication skills; Personal ethics also play an important role in competence building among graduates (Jackson and Chapman, 2012). Graduates are now accounting for the social and environmental responsibility of employers in their career choices and employers are considering the "social/environmental ethics, values and experience of university students as part of their graduate recruitment" (Cade, 2008, p. 3). Availability of core values, social responsibility and accountability is considered important for students seeking 'Manager' profile in reputed companies.

Jackson and Chapman (2011) have argued about 2 types of ethics necessary for competency building namely Personal ethics and work ethics. The Personal ethics means Remain consistently committed to and guided by core values and beliefs such as honesty and integrity and Work ethics means: Go beyond the call of duty by pitching in, including undertaking menial tasks as required by the business. Take action unprompted to achieve agreed goals. It supports the study that ethics is one of skills required by the graduates.

Kazilan et al. (2009) identified various attributes of ethics which includes: Responsibility, Self Confidence, Sociability, Self Management, Honesty, punctuality and efficiency, Adaptable and flexible, self control/self directed and good work attitude .These attributes are part of ethics.

\section{Results And Discussions}

Based on the discussions with industry executives and literature review, a comprehensive questionnaire was developed and pilot study was conducted with 10 executives from the placement teams visiting campuses. With their feedback questionnaire was improved with respect to reframing the question, making them unambiguous and also adding more aspects. This questionnaire was given to 354 executives and a total of 75 filled responses were received and out of that only 63 which are duly filled are used for analysis.

\section{Level of expectations from Engineering Graduates}

The analysis of the responses is given in Table 1 and also in figure 1. Table 1 shows that problem solving skills, design/ development of solution and ability to conduct investigations of complex problems are the three most important skills expected by the recruiters while selecting a candidate. In a way, these three skills together provide the necessary competency to the students to handle real life complex engineering problems. It is difficult to understand why the importance is very low to the 'modern tool usage'. In academic institutions lot of emphasis is on new tools, software, analytical techniques. Further from the analysis, it appears that the 
industry is still not showing maturity by not appreciating the need of ethics, synergy between engineering and society; environment and sustainability etc.

The figure 1 gives the profile of the responses to A-H attributes on a five point likert scale. It is interesting to note that the executives have responded their expectations as very high to engineering knowledge, problem solving, design and development of solutions and ability to conduct investigations of complex engineering problem.

\section{Correlation among Attributes}

In a complex real life business environment, it is the combination of skills, rather than one stand alone skills, that helps to perform efficiently and effectively. To understand the need of multiple skills requirements, correlation analysis is carried out and results are presented in table 2. The attribute engineering knowledge (A) has a strong correlation (significant at 0.01 level of significance) with design development of solution (C); modern tool usage (E) and synergy between engineering and society $(\mathrm{F})$. Also seen a strong correlation of problem analysis (B) with design development of solution (C); ability to conduct investigations (D) and ethics $(\mathrm{H})$. Design development of solution (C) has strong correlation with ability to conduct investigations (D). Ability to conduct investigations (D) in turn has strong correlation with ethics (H). Modern tool usage (E) has strong correlation with synergy between engineering and society $(\mathrm{F})$ and also with environment and sustainability $(\mathrm{G})$. This reflects that we need modern tools of engineering to address the issues of environment, sustainability and the much desired synergy with society. Further strong relations between $\mathrm{F}$ and $\mathrm{G}$ also between $\mathrm{G}$ and $\mathrm{H}$ show that environment, sustainability, ethics, synergy with society are inter related.

Table 1: Level of expectation from the engineering graduates

\begin{tabular}{|l|l|l|l|l|}
\hline Code & Attribute & Mean & SD & P value \\
\hline A & Engineering knowledge & 4.0 & 1.270 & 0 \\
\hline B & Problem analysis & 4.38 & 0.888 & 0 \\
\hline C & Design/ Development of solutions & 4.29 & 0.923 & 0 \\
\hline D & Ability to conduct investigation of complex problems & 4.17 & 0.908 & 0 \\
\hline E & Modern tool usage & 3.08 & 1.286 & $0.626^{*}$ \\
\hline F & Synergy between engineering and society & 3.02 & 1.326 & $0.925^{*}$ \\
\hline G & Environment and sustainability & 3.13 & 1.289 & $0.437^{*}$ \\
\hline H & Ethics & 3.76 & 1.201 & 0 \\
\hline
\end{tabular}

*Significant at $5 \%$ level of confidence

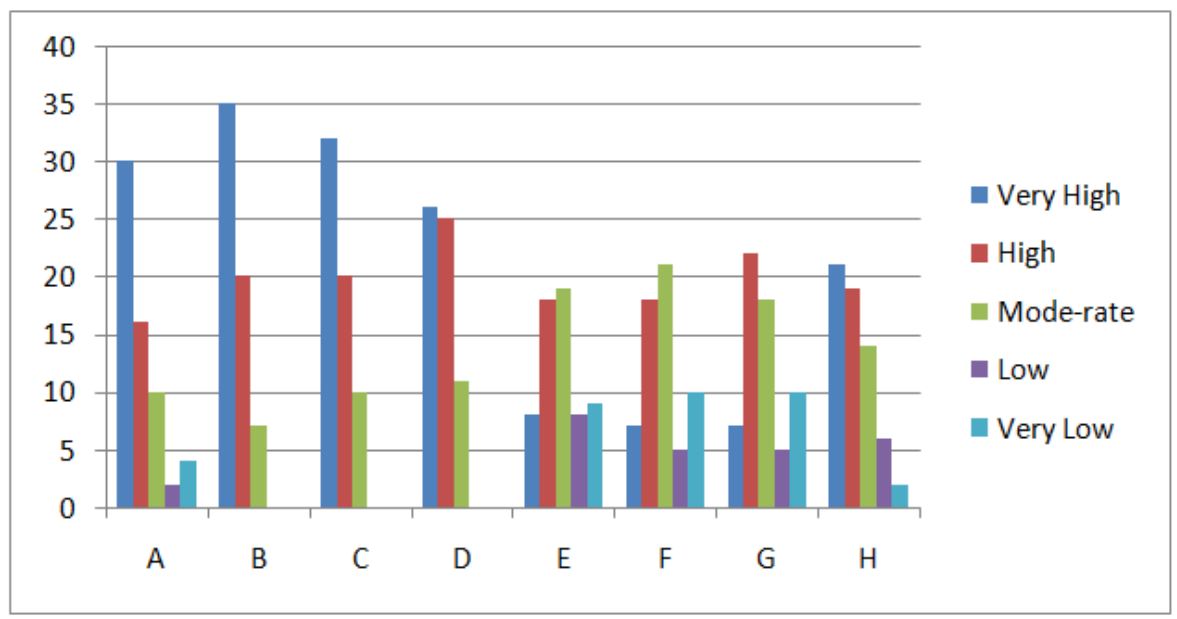

Figure 1: Profile of the responses on Likert Scale

Table 2: Correlat ion among Skill Attributes

\begin{tabular}{|c|c|c|c|c|c|c|c|c|c|}
\hline & & A & $\mathrm{B}$ & $\mathrm{C}$ & D & $\mathrm{E}$ & $\mathrm{F}$ & G & $\mathrm{H}$ \\
\hline \multirow[t]{2}{*}{ A } & Pearson Correlation & 1 & $.315^{*}$ & $.344^{* *}$ & .168 & $.346^{* * \pi}$ & $.412^{* *}$ & .246 & .127 \\
\hline & Sig. (2-tailed) & & .012 & .006 & .188 & .006 & .001 & .052 & .322 \\
\hline \multirow[t]{2}{*}{ B } & Pearson Correlation & $.315^{*}$ & 1 & $.633^{* *}$ & $.657^{* *}$ & .128 & .132 & .169 & $.510^{* *}$ \\
\hline & Sig. (2-tailed) & .012 & & .000 & .000 & .316 & .303 & .187 & .000 \\
\hline \multirow[t]{2}{*}{$\mathrm{C}$} & Pearson Correlation & $.344^{* *}$ & $.633^{* * *}$ & 1 & $.632^{* * *}$ & -.033 & .141 & .077 & $.295^{*}$ \\
\hline & Sig. (2-tailed) & .006 & .000 & & .000 & .798 & .270 & .546 & .019 \\
\hline \multirow[t]{2}{*}{$\mathrm{D}$} & Pearson Correlation & .168 & $.657^{\text {** }}$ & $.632^{* *}$ & 1 & .043 & .199 & .215 & $.512^{* *}$ \\
\hline & Sig. (2-tailed) & .188 & .000 & .000 & & .737 & .118 & .090 & .000 \\
\hline \multirow[t]{2}{*}{$\mathrm{E}$} & Pearson Correlation & $.346^{* *}$ & .128 & -.033 & .043 & 1 & $.586^{* * *}$ & $.451^{* *}$ & $.273^{*}$ \\
\hline & Sig. (2-tailed) & .006 & .316 & .798 & .737 & & .000 & .000 & .030 \\
\hline
\end{tabular}


Skills Requirements for Engineering Graduates: Industry Perspective

\begin{tabular}{|c|c|c|c|c|c|c|c|c|c|}
\hline \multirow[t]{2}{*}{$\mathrm{F}$} & Pearson Correlation & $.412^{* *}$ & .132 & .141 & .199 & $.586^{* *}$ & 1 & $.697^{* *}$ & $.286^{*}$ \\
\hline & Sig. (2-tailed) & .001 & .303 & .270 & .118 & .000 & & .000 & .023 \\
\hline \multirow[t]{2}{*}{ G } & Pearson Correlation & .246 & .169 & .077 & .215 & $.451^{* *}$ & $.697^{* *}$ & 1 & $.489^{* *}$ \\
\hline & Sig. (2-tailed) & .052 & .187 & .546 & .090 & .000 & .000 & & .000 \\
\hline \multirow[t]{2}{*}{$\mathrm{H}$} & Pearson Correlation & .127 & $.510^{* *}$ & $.295^{*}$ & $.512^{* * *}$ & $.273^{*}$ & $.286^{*}$ & $.489^{* \pi}$ & 1 \\
\hline & Sig. (2-tailed) & .322 & .000 & .019 & .000 & .030 & .023 & .000 & \\
\hline
\end{tabular}

\section{Conclusions}

In higher technical education system, industry is considered as external customers whereas students as internal customers. It is important to understand the perspective of the industry executives regarding skills required in engineering graduates. In the present business environment, graduates with a degree no longer automatically qualify for their first job. Instead, graduates who possess the greatest knowledge and skills in their domain of study are the first to be employed. The study suggests two focus areas skill development in engineering education: one as subject skills and other as generic skills. Generic skills refer to certain personal abilities of an individual, which can be taken from one job role to another, used within any profession and at any stage of his/her career while subject skills are more relevant to ones career. The correlation analysis reveals that the skills are effective when they are available as a set of skills as there is strong correlation among certain skills in their requirements by the industry. The study will be useful to the students, faculty and management of the institutes in developing the right curriculum, providing the necessary skills and helping the industry in providing right human resource thus contributing to the economic progress of the country.

\section{References}

[1]. Adeyemo, S.A., Ogunleye, A.O., Oke, C.O. and Adenle, S.O. (2010), A survey of factors determining the employability of science and technology graduates of polytechnics and universities in the Nigerian labour market, Journal of Science and Technology Education Research, Vol. 1 No. 5, pp. $99-106$

[2]. Andriušaitienè, D. (2014), Model of organization of VET teachers' technological competences development - the lesson of social partnership, Procedia - Social and Behavioral Sciences, Vol. 110, pp. 647 - 657.

[3]. Azevedo, A., Apfelthaler, G. and Hurst, D. (2012), Competency development in business graduates: An industry-driven approach for examining the alignment of undergraduate business education with industry requirements, The International Journal of Management Education, Vol. 10, pp. 12-28.

[4]. Baharom, M.N.R., Salleh, R., Sivapalan, S., Ali, R.M.M. and Abdullah, A. (2014), Gauging business acumen level of technical students from Universiti Teknologi PETRONAS: Views from the Malaysian Industry, Procedia - Social and Behavioral Sciences, Vol. 116, pp. $4683-4688$.

[5]. Bektaş, C. and Tayauova, G. (2014), A Model Suggestion for Improving the Efficiency of Higher Education: University-Industry Cooperation, Procedia - Social and Behavioral Sciences, Vol. 116, pp. 2270 - 2274.

[6]. Belski I., Baglin J. and Harlim J. (2013), Teaching TRIZ at University: a Longitudinal Study, International Journal of Engineering Education, Vol. 29, pp. 346-354.

[7]. Belski I. (2015), TRIZ Education: Victories, Defeats and Challenges (in English), Образовательные Технологии (Educational Technologies), pp. 83-92.

[8]. Belski, I., Adunka, R. and Mayer, O. (2016), Educating a Creative Engineer: Learning from Engineering Professionals, Procedia CIRP, Vol. 39, pp. $79-84$

[9]. Bhuasiri, W., Xaymoungkhoun, O., Zo, H., Rho, J.J. and Ciganek, A.P. (2012), Critical success factors for e-learning in developing countries: A comparative analysis between ICT experts and faculty Computers \& Education, Vol. 58, pp. 843-855.

[10]. Cade, A. (2008), Employable graduates for responsible employers: Research on the links between sustainability and employability in the graduate job market in relation to higher education teaching and learning. York: Higher Education Academy.

[11]. Collet, C., Hine, D. and du-Plessis, K. (2015), Employability skills: perspectives from a knowledge-intensive industry, Education + Training, Vol. 57, No. 5, pp. 532-559.

[12]. Davey, B. and Tatnall, A. (2008), Where will professional software engineering education go next? IFIP International Federation for Information Processing, Learning to Live in the Knowledge Society, Vol. 281, pp. 185-192.

[13]. Douglas E.P., Koro-Ljungberg M., McNeill N.J., Malcolm Z.T. and Therriault D.J. (2012), Moving beyond formulas and fixations: solving open-ended engineering problems, European Journal of Engineering Education, Vol. 37, pp. 627-651.

[14]. Engineering Council. UK, Standard for Professional Engineering Competence. Engineering Council; 2013.

[15]. Gan, B., Menkhoff, T. and Smith, R. (2015), Enhancing students' learning process through interactive digital media: New opportunities for collaborative learning, Computers in Human Behavior, Vol. 51, pp. 652-663.

[16]. Gartner, (2005), The IT Professional Outlook: Where Will We Go From Here? Gartner, Orlando, FL.

[17]. Glomann, L.R. (2015), Human-centered design curriculum for multidisciplinary application at design faculties, Procedia Manufacturing, Vol. 3, pp. $3551-3558$.

[18]. Jackson, D. and Chapman, E. (2011), Non-technical competencies in undergraduate business degree programs: Australian and UK perspectives, Studies in Higher Education, Accessed by. http://dx.doi.org/10.1080/03075079.2010.527935.

[19]. Jackson, D. and Chapman, E. (2012), Empirically derived competency profiles for Australian business graduates and their implications for industry and business schools, The International Journal of Management Education, Vol. 10, pp. 112-128.

[20]. Johan, K. (2015), Perception of Students Towards Lecturers Teaching Engineering Courses With Industry Experience: A Case Study In Malaysia Technical University, Procedia - Social and Behavioral Sciences, Vol. 195, pp. 925 - 934.

[21]. Kazilan, F., Hamzah, R. and Bakar, A.R. (2009), Employability Skills Among the Students of Technical and Vocational Training Centres in Malaysia, European Journal of Social Sciences, Vol. 9, No. 1.

[22]. Kiron, D., Kruschwitz, N., Haanaes, K., von Steng Velken, I. (2012), Sustainability nears a tipping point. MIT Sloan Manag. Rev., Vol. 53, pp. 69-74. 
[23]. Lozano, R., Lozano, F.J., Mulder, K., Huisingh, D. and Waas, T. (2013), Advancing higher education for sustainable development: international insights and critical reflections. J. Clean. Prod., Vol. 48, pp. 3-9.

[24]. McKeown, R., Hopkins, C.A., Rizzi, R. and Chrystalbridge, M. (2002), Education for Sustainable Development Toolkit. Version 2, Waste Management Research and Education Institute, University of Tennessee, USA. Available at: http://www.esdtoolkit.org/.

[25]. McMurray, S., Dutton, M., McQuaid, R. and Richard, A. (2016), Employer demands from business graduates, Education + Training, Vol. 58 Iss 1 pp. 112 - 132.

[26]. Moreno, A.M., Segura, M.I.S., Dominguez, F.M. and Carvajal, L. (2012), Balancing software engineering education and industrial needs, The Journal of Systems and Software, Vol. 85, pp. 1607-1620.

[27]. Murali. S and Rajaram, Y. (2015), A Study on the Corporate Expectations from Engineering Graduates in India - Bangalore, IOSR Journal of Business and Management, Vol. 17, Issue 6, Ver. III, pp 01-09.

[28]. NASSCOM Report (2015) India

[29]. National Knowledge Commission Report (2009)

[30]. Remaud, B., Martin, R.P. Sánchez, T. and Arditti, J.C. (2010), Using industry internships to improve the quality of engineering higher education in Europe. The experience of French graduate engineering schools 2nd International Conference: Institutional Strategic Quality Management - ISQM2010 14 - 16 October 2010, Sinaia, Romania Paper ID: 035-ISQM2010.

[31]. Rieckmann, M. (2012), Future-oriented higher education: which key competencies should be fostered through university teaching and learning? Futures, Vol. 44, No. (2), pp. 127-135.

[32]. Shamshina, I.G. (2014), Professional competences necessary for the bachelor-degree-holding engineer specialising in engineering industries, Pacific Science Review, Vol. 16, pp. 85-94.

[33]. Sharma, V. (2012), A perceptual study on KM orientation in Indian private engineering institutions, International Journal of Educational Management, Vol. 26 No. 3, pp. 234-251.

[34]. Sibbel, A. (2009), Pathways towards sustainability through higher education. Int. J. Sustain. High. Educ., Vol. 10, No. (1), pp. 6882.

[35]. Steiner, L., Sundstr€om, A. and Sammalisto, K. (2013), An analytical model for university identity and reputation strategy work. High. Educ., Vol. 65 (4), pp. 401-415.

[36]. Webster, C.M. and Kenney, J. (2011), Embedding research activities to enhance student learning, International Journal of Educational Management, Vol. 25, No. 4, pp. 361-377.

[37]. Wickramasinghe, V. and Perera, L. (2010), Graduates', university lecturers' and employers' perceptions towards employability skills, Education + Training, Vol. 52 No. 3

[38]. Yeo, R.K. (2009), Service quality ideals in a competitive tertiary environment, International Journal of Educational Research, Vol. 48, pp. 62-76.

[39]. Zaharim, A., Yusoff, Y.M., Omar, M.Z., Mohamed, A. and Muhamad, N. (2010), Employers' Perceptions and Expectation toward Engineering Graduates: A Study Case, Proceedings of the 6th WSEAS International Conference on Engineering education. 